\title{
ТЕОРЕТИЧНІ АСПЕКТИ РОЗВИТКУ ПРОФЕСІЙНОЇ МОБІЛЬНОСТІ МАЙБУТНІХ БАКАЛАВРІВ СЕСТРИНСЬКОЇ СПРАВИ
}

\author{
О. В. Ткалич
}

\author{
Кіровоградський медичний фаховий коледж ім. Є. Й. Мухіна
}

\begin{abstract}
За умов безперервного зростання і розвитку сучасної системи охорони здоров’я виникають нові вимоги до професійно-особистісної характеристики бакалаврів сестринської справи. Вони, зокрема, зумовлюють необхідність оновлення змісту професійної підготовки медсестер-бакалаврів, формування особистісних та професійних якостей. Пріоритетною для затребуваного бакалавра сестринської справи стає професійна мобільність, яка дає змогу оперативно реагувати на будь-які професійно значущі зміни, ефективно діяти в складних ситуаціях, приймати самостійні професійно грамотні та ефективні рішення.
\end{abstract}

\section{THEORETICAL ASPECTS OF DEVELOPMENT OF PROFESSIONAL MOBILITY OF FUTURE BACHELORS OF NURSING}

\author{
O. V. Tkalych
}

\section{Ye. Mukhin Kirovohrad Medical Professional College}

In terms continuous growth and development of the modern health care system there are new requirements for the professional and personal characteristics of bachelors of nursing. They, in particular, necessitate updating the content of professional training of bachelor nurses, formation of personal and professional qualities. Professional mobility becomes a priority for the demanded bachelor of nursing, which allows you to quickly respond to any professionally significant changes, act effectively in difficult situations, make independent professionally competent and effective decisions.

Вступ. У сучасних умовах медсестринська освіта відіграє найважливішу роль в розвитку системи охорони здоров'я. Сучасна освітня парадигма розглядає студента як основну мету освіти; вчить аналізувати і вивчати попередній досвід; допомагає розпізнати потреби і мотиви; надає допомогу і підтримку в саморозвитку; вчить формулювати, займати і відстоювати власну позицію, брати участь у визначенні власної освітньої траєкторії; готує до безперервної освіти протягом життя; вчить жити «тут і тепер» [5]. Сучасна освітня парадигма передбачає створення власного образу світу і власного образу в цьому світі, вчить толерантності, збереження і розвитку індивідуальності, постійної зміни ролей, бути мобільною особистістю в динамічному світі.

Основна частина. Зміни, які відбуваються в сучасній Україні та в системі освіти зокрема, здійснюють значний вплив на майбутніх фахівців. Тому сучасна освіта покликана допомогти молодим фахів-

(c) О. В. Ткалич, 2021 цям бути стійкими до змін і здатними до реактивної адаптації, тобто бути мобільними. Традиційно прийнято розрізняти професійну і соціальну мобільність та аналізувати їх у форматі чітких і певних характеристик. В українському педагогічному енциклопедичному словнику термін «мобільність» (з англ. mobility, з нім. mobilitat) характеризується як рухливість, готовність і здатність до зміни стану, положення [2]. Тобто мобільність співвідноситься з поняттям руху. У психологічній енциклопедії термін «мобільність» по суті розглядається, буквально, як фізичний рух організму, а метафорично - рух особистості крізь сфери: соціальні, професійні, пізнавальні [4].

Проблеми вивчення механізмів саморуху особистості в житті та діяльності, ії активності, мобільності цікавили ще античних дослідників. Запроваджене Арістотелем поняття акту і потенції було зведено до більш об'ємного і широкого поняття - «енергія». Спираючись на його уявлення, варто констатувати, що енергія акту (процесу), як правило, мобілізує осо-

64 ISSN 2411-1597. МЕДСЕСТРИНСТВО. 2021. № 2 
бистість, сприяє ії активності, тоді як інша енергія сприяє здійсненню речі (ентелехія), є результатом діяльності та має основу для потенційної активності. Однак і в цьому випадку Арістотель розглядав всю природу як послідовний перехід від «матерії» до «форми» і назад. У матерії Арістотель бачив лише пасивний початок, а формі приписував всю активність [1].

3 огляду на це, цікавим $є$ розуміння мобільності не лише як динамічної характеристики суб'єкта, а й як діяльності, що зачіпає психічну сферу особистості. Так, Н. Латуша заявляє, що мобільність є найважливішим виявом соціалізації особистості. Тому мобільність варто розглядати як готовність не лише до зміни місця роботи, проживання, а також характеру дозвілля та соціальної групи тощо [3]. Ці два феномени - особистісна мобільність і соціалізація знаходяться в полі інтересів педагогів, оскільки наявність якостей мобільності особистості сприяє її успішній соціалізації в суспільстві. І, навпаки, успішна соціалізація сприяє розвитку цих якостей. Соціальна поведінка - пристосування окремо взятої особистості до мінливих умов середовища одночасно $\in$ способом перетворення цього середовища. У цьому контексті не враховано аспект перетворення «себе», який передбачає оволодіння особистістю методами дослідницького підходу власної діяльності, що, безумовно, $\epsilon$ перешкодою до усвідомлення нею необхідності постійної професійної освіти і саморозвитку.

Початком для конкретизації поняття «професійна мобільність» $є$ поняття «соціальна мобільність», яке належить до понятійної бази філософії, соціології, педагогіки та психології. Суть цього терміна передбачає зміну індивідом або групою осіб місця, займаного в соціальній структурі, або переміщення з одного соціального шару в інший [1]. Тому варто говорити про вертикальну і горизонтальну соціальну мобільність. Вертикальна соціальна мобільність передбачає переміщення індивіда чи групи в системі соціальної ієрархії зі зміною соціального статусу. Тоді як горизонтальна мобільність передбачає переміщення індивіда або групи в соціальній структурі без зміни соціального статусу (зміна релігії, громадянства, сім'ї, професії, місця проживання, місця роботи).

На думку Л. Сушенцевої, професійна мобільність ґрунтується на зміні групою осіб або індивідом однієї професії на іншу. Авторка розрізняє вертикальну професійну мобільність (переміщення вгору-вниз у професійно-кваліфікаційній структурі) та горизонтальну (переміщення без якісної зміни професії і кваліфікації) [5]. Однак не варто розглядати професійну мобільність як процес переміщення працівників між професійними і кваліфікаційними групами в результаті набуття виробничого досвіду, практичних знань і навичок. Припускаємо, що професійна мобільність це, передусім, здатність і готовність особистості досить швидко й успішно оволодівати новою технікою і технологією, опановувати необхідні знання та вміння для забезпечення ефективності нової профорієнтаційної діяльності.

У понятті «професійна мобільність» Н. Латуша розрізняє об'єктивні, суб'єктивні та характерологічні аспекти. Об'єктивний аспект охоплює науково-технічні та соціально-економічні передумови, а також сам процес зміни професії. Суб'єктивний аспект передбачає процес зміни інтересів працівника й акт прийняття рішення про зміну місця роботи або професії. 3 характерологічної точки зору, професійна мобільність розглядається як стійка властивість особистості, як підготовленість або схильність до зміни виду професійної діяльності [3]. Сутнісними проявами професійної мобільності суб'єкта в професійній діяльності $\epsilon$ : процес руху між групами професійної структури суспільства; повна або часткова зміна професійного статусу; зміна змісту професійної діяльності; зміна рівня кваліфікації; зміна позиції в системі розподілу влади в професійній діяльності; збільшення автономності професійної діяльності; зміна рівня матеріального забезпечення в професійній діяльності [1].

Зазвичай професійна мобільність ототожнюється з творенням цінностей, моральних установок, тому проблема професійної мобільності - проблема розвитку і зміни людських цінностей, сфери їхньої дії, конфліктів між новими і традиційними цінностями та шляхів подолання. У міру розвитку суспільства (як прогресивного, так і регресивного) створюються нові умови, які одночасно сприяють повнішій реалізації людиною самої себе, власних можливостей і вимагають адекватної оцінки ситуації, що змінюється, вміння не лише адаптуватися до цих нових динамічних умов, а також переорієнтуватися і переоцінювати нові професійні реалії.

Будь-які процеси самотворення ініціюються, підтримуються і формуються особистістю завдяки мобільності: рухомості свідомості та гнучкості ціннісносмислових структур. Ця особливість мобільності як 
якості особистості дає змогу говорити про ії «творчі функції», творчо спрямовану енергетику. Ї̈̈ джерелом $\epsilon$ духовний потенціал особистості, внутрішні сили, прагнення змінити і поліпшити навколишній світ [5].

3 огляду на це, професійна мобільність - це не просто декларована освітня стратегія, вона породжена часом і $є$ відображенням світових освітніх тенденцій, а готовність до мобільності $€$ одночасно умовою і наслідком світових інтеграційних процесів. Професійна мобільність - це інтегративна якість особистості, яка охоплює: сформовану внутрішню потребу в професійній мобільності, здатності та «знаннєву» основу професійної мобільності, а також самоусвідомлення особистістю своєї професійної мобільності, сформоване на основі рефлексії готовності до професійної мобільності. Кожна з цих складових охоплює певні підструктури, розвиток яких і забезпечує результат - ії формування. В основі формування потреби у професійній мобільності лежать: розвиток мотивації самоосвіти, розвиток мотивації досягнення, формування установки на самоактуалізацію, установка на оптимістичне сприйняття дійсності, зміни професії. Здібності до професійної мобільності передбачають розвинені когнітивні здібності, креативність, дивергентність, критичність мислення. «Знаннєва» основа професійної мобільності охоплює загальноосвітні, загальнопрофесійні, практичнопрофесійні знання, ключові кваліфікації та компетенції, здатність до швидкого переносу знань.

Модернізація медсестринської освіти вносить у розуміння мобільності професіонала особливий

\section{СПИСОК ЛІТЕРАТУРИ}

1. Андрущенко В. Філософія : підручник / В. Андрущенко. - 2-ге вид., переробл. та доповн. - Х. : Консум, 2000. - 672 c.

2. Гончаренко С. У. Український педагогічний енциклопедичний словник / С. У. Гончаренко. - 2-ге вид., доповн. і випр. - Рівне : Волинські обереги, 2011. - 552 с.

3. Латуша Н. В. Поняття «професійна мобільність»у педагогічному аспекті / Н. В. Латуша // Наукові записки Вінницького державного педагогічного університету сенс, пов'язаний з розвитком довгострокових і гнучких компетенцій, на базі яких уможливлюється побудова кар'єри та досягнення професійних висот. Професія медичної сестри передбачає отримання певної формальної освіти та регулярне підвищення кваліфікації. 3 одного боку, це знижує шанси на мобільність шляхом локальності освіти, низького рівня ії̈ конвертованості. 3 іншого - підвищує мобілізаційні можливості порівняно з іншими професійними групами.

Висновки. Професійну мобільність необхідно розглядати як: якість особистості, що забезпечує внутрішній механізм вдосконалення і розвитку людини; діяльність людини, що визначається змінними подіями, та в результаті якої відбувається самореалізація особистості в ії̈ професії і житті; процес самовдосконалення особистості та її професійного середовища. Сучасному бакалавру сестринської справи необхідно володіти професійною мобільністю, оскільки їх діяльність динамічна: цілі, залежні від цілей держави й ії політики; студент як суб'єкт навчання; умови соціального середовища; навчальна інформація, яка піддається постійній зміні під впливом науково-технічного прогресу. Нестандартність медичних ситуацій передбачає те, що медсестра кожен раз проявляється в нових обставинах. Медсестринська діяльність не статична по своїй суті, вона ставить все нові й нові вимоги перед медсестрами, вимагаючи щораз унікальних, творчих рішень.

імені Михайла Коцюбинського. - 2014. - № 42 (2). С. 6-9. - (Серія «Педагогіка і психологія»).

4. Психологічна енциклопедія / [авт.-упоряд. О. М. Степанов]. - К. : Академвидав, 2006. - 424 с.

5. Сушенцева Л. Л. Проблема професійної мобільності у контексті міждисциплінарного підходу / Л. Л. Сушенцева // Теорія і методика професійної освіти. - 2011. № 1. - С. 3-11. 